\title{
Transition State Structure of RNA Depurination by Saporin L3
}

\author{
Hongling Yuan, Christopher F. Stratton and Vern L. Schramm* \\ Department of Biochemistry, Albert Einstein College of Medicine, 1300 Morris Park Avenue, Bronx, New York 10461
}

\section{SUPPORTING INFORMATION}

Synthesis of $\left[7-{ }^{15} \mathrm{~N}\right]-$ and $\left[9-{ }^{15} \mathrm{~N}\right]$ adenines.

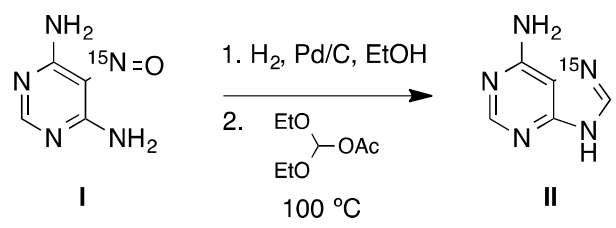

Supplementary Figure S1. Synthesis of $\left[7-{ }^{15} \mathrm{~N}\right] \operatorname{adenine}($ II).

$\left[7-{ }^{15} \mathrm{~N}\right]$ Adenine (II). $\left[7-{ }^{15} \mathrm{~N}\right]$ adenine (II) was synthesized from 4,6-diamino-5- $\left[{ }^{15} \mathrm{~N}\right]$ nitrosopyrimidine (I) using methods adapted from Sethi et al. ${ }^{52}$ In a flame-dried, Ar-flushed flask equipped with magnetic stir bar and septum, nitrosopyrimidine (I) $(20.0 \mathrm{mg}, 0.144 \mathrm{mmol})$ was suspended in absolute $\mathrm{EtOH}(16.0 \mathrm{~mL})$. A spatula tip of $\mathrm{Pd}$ on carbon $(10 \mathrm{wt} . \%)$ was added to the suspension and the flask was purged with $\mathrm{H}_{2}$ for 20 minutes. The flask was fitted with a balloon of $\mathrm{H}_{2}$ and the suspension was stirred overnight at room temperature. The next day, the suspension was filtered through a pad of celite $(\mathrm{EtOH})$ and the filtrate was concentrated to dryness by rotary evaporation. The crude product was suspended in diethoxymethyl acetate $(2.5 \mathrm{~mL})$ and stirred at $100^{\circ} \mathrm{C}$ overnight in a sealed, thick-walled flask. The next morning, the reaction was cooled to room temperature and concentrated by rotary evaporation. The crude product was purified via HPLC on a Phenomenex Luna ${ }^{\circledR} 5 \mu \mathrm{m} \mathrm{C}_{18}$ column $(250 \mathrm{x}$ $10.0 \mathrm{~mm}, 100 \AA$ ) using an isocratic solvent system of $4 \% \mathrm{MeCN}$ in $\mathrm{H}_{2} \mathrm{O}$. Fractions containing $\left[7-{ }^{15} \mathrm{~N}\right]$ adenine were combined, frozen, and the solvent was removed via lyophilization to provide (II) as a white solid. Analytical data were in agreement with literature precedent.
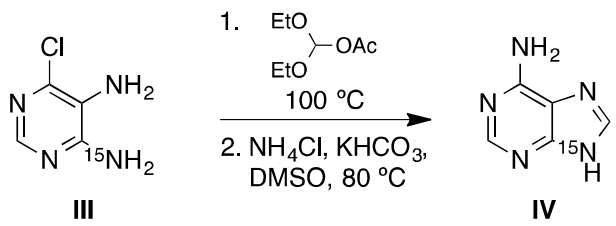

Supplementary Figure S2. Synthesis of $\left[9-{ }^{15} \mathrm{~N}\right]$ adenine (IV). 
$\left[9-{ }^{15} \mathrm{~N}\right]$ Adenine (IV). $\left[9-{ }^{15} \mathrm{~N}\right]$ Adenine (IV) was synthesized from $\left[4-{ }^{15} \mathrm{~N}\right]$ diamino-6-chloropyrimidine (III) using methods adapted from Sethi et $a l^{52}$ and Jones et $a l^{53}$ In a flame-dried, Ar-flushed thick-walled flask, chloropyrimidine (III) $(10.0 \mathrm{mg}, 0.0687 \mathrm{mmol})$ was dissolved in diethoxymethyl acetate $(1.5 \mathrm{~mL})$. The flask was sealed and the mixture was stirred at $100{ }^{\circ} \mathrm{C}$ overnight. The next day, the reaction was cooled to room temperature and concentrated to dryness by rotary evaporation. The crude product was dissolved in dry DMSO $(2.0 \mathrm{~mL})$ in a flame-dried, Ar-flushed $4.0 \mathrm{~mL}$ vial equipped with magnetic stir bar and septum. $\mathrm{KHCO}_{3}(41.2 \mathrm{mg}, 0.412 \mathrm{mmol})$ and $\mathrm{NH}_{4} \mathrm{Cl}(14.6 \mathrm{mg}, 0.274 \mathrm{mmol})$ were added to the solution, the vial was sealed with a Teflon cap, and the reaction was stirred at $80{ }^{\circ} \mathrm{C}$ for three days. The reaction was then cooled to room temperature, diluted with $\mathrm{H}_{2} \mathrm{O}$, and filtered through a pad of celite $\left(\mathrm{H}_{2} \mathrm{O}\right)$. The crude product was purified via HPLC on a Phenomenex Luna ${ }^{\circledR} 5$ $\mu \mathrm{m} \mathrm{C}_{18}$ column $(250 \times 10.0 \mathrm{~mm}, 100 \AA)$ using an isocratic solvent system of $4 \% \mathrm{MeCN}$ in $\mathrm{H}_{2} \mathrm{O}$. Fractions containing $\left[9-{ }^{15} \mathrm{~N}\right]$ adenine were combined, frozen, and solvent was removed via lyophilization to afford (IV) as a white solid. Analytical data were in agreement with literature precedent.

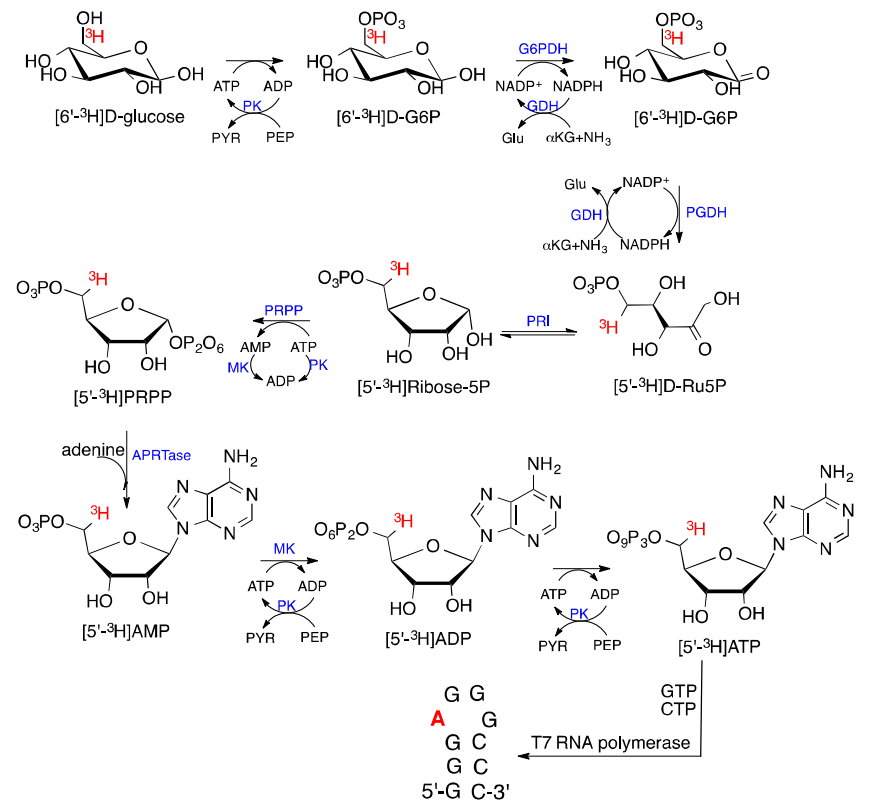

Supplementary Figure S3. Synthesis of isotopically labeled stem-loop RNAs. 